\title{
Adaptation and validation of a questionnaire about risk behaviors for AIDS among drug users
}

\section{Adaptação e validação de questionário sobre comportamentos de risco para Aids em usuários de droga}

\author{
Flavio Pechansky ${ }^{\mathrm{a}}$, Vânia Hirakata ${ }^{\mathrm{b}}$ and David Metzger ${ }^{\mathrm{c}}$
}

${ }^{a}$ Research Group on Drug Dependence of the Clinical Hospital of Porto Alegre. Porto Alegre, RS, Brazil. 'bepartment of Psychiatry, School of Medicine, Federal University of the State of Rio Grande do Sul. Porto Alegre, RS, Brazil. 'Department of Psychiatry, School of Medicine of the University of Pennsylvania. Pennsylvania, USA

\begin{abstract}
Objectives: To initiate the process of validation of an instrument based on an American self-reported questionnaire named RAB (Risk Assessment Battery) - called CRA in its Brazilian version -, which covers aspects related to drug use, HIV testing, sexual behavior and concern with the transmission of the virus. The questionnaire was back-translated and its concurrent validity was tested, as well as the utility of an Overall Risk Score (ORS) for the transmission of the HIV virus or of subscores for Drug Use (SDU) or Sexual Risk (SSR).

Methods: Case vignettes of ten typical cases had their questionnaire scores compared with the impression of independent referees.

Results: There were systematic differences in the comparison with the specific referees for each area, suggesting that only the ORS has clinical validity, specifically regarding the exposure to risk of infection/ reinfection by HIV.

Conclusion: The questionnaire in its current use and format is not adequate to express impairment already caused by exposure to the virus. The specific subscores were not clinically valid to express such risk, and the instrument needs the addition of a more comprehensive section about intravenous drug use to be used in future studies.
\end{abstract}

Keywords HIV seroprevalence. AIDS. Risk behaviors. Street drugs. Validation studies (publication type).

Resumo Objetivos: Iniciar o processo de validação da versão brasileira de um instrumento americano de coleta de dados auto-aplicável denominado CRA (Comportamentos de Risco para Aids), que cobre aspectos relativos a uso de drogas, testagem para HIV, comportamento sexual e preocupação com a transmissão do vírus. O instrumento foi submetido à tradução reversa e validação concorrente. $\mathrm{O}$ trabalho também teve o intuito de testar a utilidade de um escore geral de risco (EGR) para a transmissão do vírus HIV ou de subescores de risco para uso de drogas (ERUD) e para risco sexual (ERS).

Métodos: Vinhetas clínicas de dez casos típicos tiveram seus escores CRA comparados ao julgamento de juízes independentes.

Resultados: Na comparação com os juízes das áreas específicas, houve diferenças sistemáticas, sugerindo que apenas o EGR tem validade clínica e, especificamente, no que compete à exposição a risco de infecção/reinfecção pelo HIV.

Conclusão: $O$ instrumento em sua forma e utilização atuais não é adequado para expressar comprometimento já causado pela exposição ao vírus. Os subescores específicos não foram clinicamente válidos para expressar tal risco, e o instrumento necessita do acréscimo de uma seção mais abrangente sobre uso de drogas injetáveis para utilização em estudos posteriores.

Descritores Soroprevalência de HIV. Aids. Comportamento de risco. Drogas ilícitas. Estudos de validação (tipo de publicação). 


\section{Introduction}

One of the difficulties in dealing with HIV infection is that its main forms of propagation are by modes of transmission that are scarcely socially tolerated or contrary to the current social habits of the majority of the population, such as the shared use of intravenous drugs and male homosexuality. Prejudice towards these behaviors has promoted the avoidance of subjects at risk by identifying them as a 'risk group'. Curran, cited by Swan' described the process of segregating subjects with AIDS into 'slums' or 'ghettoes', minimizing its dissemination in the general population and, therefore, contributing to the impression that actually there were specific risk foci isolated from the society.

Studies in the 90' $\mathrm{s}^{2-4}$ decreased this bias as they identified a modification towards a trend of dissemination of HIV in the heterosexual and bisexual populations, contributing, therefore, to a greater democratization of preventive efforts; they also highlighted how little understood these modes of sexual transmission were when compared to the modes admitted today. Thus, the concept of 'risk groups' gave place to that of 'risk situations', to which, theoretically, any subject could be exposed in varied intensities. Figueiredo, Miranda \& Marques ${ }^{5}$ stressed the need to know more in detail the habits that lead to risk circumstances for HIV infection as the only way to fight the epidemic. It is essential to know the characteristics of risk exposure to which a particular subject is subjected in a specific period of his/her life in order to design effective programs for specific populations on which they are meant to produce an impact. ${ }^{6}$ Although this information is difficult to obtain, its utilization may strongly modify personal health behaviors, ${ }^{7,8}$ what justifies the degree of invasion of privacy to collect it.

In Brazil there is an absolute lack of standardized methods to assess situations of risk exposure to HIV, as well demonstrated by Dunn and Laranjeira, ${ }^{9,10}$ who criticize the various sources or the development of instruments by authors themselves without the appropriate process of validation, preventing studies to be comparable. The Risk Behavior Assessment instrument, developed in the US by the national institute on drug abuse and adapted for its use in Brazil by Telles et al, ${ }^{11}$ can be an example. In this semi-structured interview, which assesses the risk exposure in drug users, entire blocks of questions - such as the section about the involvement with drugs that do not exist in Brazil - are not appropriately comparable to the local culture.

Due to the context mentioned above, the objective of this article is to describe the adaptation and validation of a questionnaire about risk situations for HIV transmission among drug users, testing the utility of an Overall Risk Score for transmission of the HIV or of risk subscores (Score for Drug Use and Score for Sexual Risk) derived from the standard instrument that was used.

\section{Methods}

\section{Subjects}

Subjects submitted to pilot studies, as well as those described in the clinical vignettes for our study, were volunteers of both genders, ages ranging from 15 to 60 years, who in the month prior to the interview had frequently or daily used any drug, associated to any risk behavior for HIV infection and who spontaneously sought the Serological Orientation Centers of the City Hall of Porto Alegre and of the state of Rio Grande do Sul for testing their HIV condition for free, or who were under treatment in the Chemical Dependence Outpatient Setting of the Clinical Hospital of Porto Alegre - HCPA - (first pilot study see bellow).

\section{Instrument}

In order to adapt the instrument, we developed a three-phase pilot study. Since in 1998, when the first pilot-study was carried out, there was no Portuguese questionnaire or scale to be used, we decided to use the original questionnaire that the University of Pennsylvania had been testing in its longitudinal studies the RAB (Risk Assessment Battery), ${ }^{12-15}$ a self-applicable instrument which assesses risks associated to drug use and sexual behavior during the six months prior to the interview. The RAB, according to preliminary studies in the US, seemed to be an accurate and efficient measure of risk behaviors among American intravenous drug users (IDUs). It was created to be used in the urban environment of the city of Philadelphia and was later expanded to other centers in the US. The levels of concordance between the RAB and the same questions made by an interviewer varied from $87.6 \%$ to $97.5 \%$ (Kappa test).Its test-retest reliability was 0.81 for the drug score, 0.68 for the gender score and 0.75 for the overall score - for heroin users -, and $0.74,0.90$ and 0.88 , respectively, for cocaine users (Kappa test).* Reliability rates, both for an overall score and for specific subscores, in a computer-managed version, were always above 0.84 (Pearson's test) when compared to the written version. ${ }^{15}$ As the RAB was essentially developed for heroine and intravenous cocaine users, in its Portuguese adaptation all its section about intravenous drugs was initially suppressed, mainly in the aspects referred to heroine, thought to be hardly used in Brazil. In its first translated version, the RAB was applied to 16 consecutive patients who volunteered for treatment. This group met criteria for cocaine dependence or abuse and was chosen to fill in the RAB as their socioeconomic and literacy levels were apparently comparable to Philadelphia's middle class standards. According to the respondent's reports, the RAB was well accepted and seemed to be easily applicable in this population. Several adaptations were needed regarding the reading skills when the RAB was used in a population with a lower socioeconomic profile during the following phase of its adaptation. Next, we developed a Portuguese module for the interviewers and tested it in a 10hour training session, with material provided by the American center. After all revisions, a second version - that incorporated the suggestions of the initial collectors - was developed and tested in a convenience sample with 61 volunteers in different places in Porto Alegre. ${ }^{16}$ After the definition of the version to be used in the fieldwork, one of the authors made a back trans-

*Metzger DS, Navaline H, Woody GE. Assessment of substance abuse: HIV risk assessment battery. In: Carson-Dewitt, editor. Encyclopedia of drugs, alcohol and addictive behavior. Michigan: Macmillan Reference USA, Farmington Hills; 2001. (in press). 
lation into English. Copies were sent to US partners who revised the translation and found that questions did not differ significantly from their original English format. A third version of the instrument, called CRA (Brazilian abbreviation for AIDS Risk Behavior - Comportamento de Risco para Aids)* was developed, based on the changes proposed by collectors of the two first collections and on the confirmation of the similarity of the Brazilian and American versions. The CRA, in its current form, is a self-applicable questionnaire which covers aspects of drug use, HIV testing, sexual behavior and concern with the transmission of the HIV. As a rule, it can be applied to literate patients without an interviewer and its application takes 10 minutes on average. Its 38 questions cover mostly a period between 6 months up to 30 days before the data collection and the answers are presented in ordered categories, each one receiving a numeric value as in the example bellow:

- During the last month, how frequently have you used marijuana?
[ ] $0=$ Not even once
[ ] $1=$ A few times
[ ] $2=$ Almost always
[ ] 3= Every day

In a field stage, after the initial utilization of the questionnaire to collect descriptive information related to the drug use and associated risk behaviors in this sample, we aimed to integrate the instruments' questions in a score that would depict the intensity of risk exposure to HIV infection by subjects who answered the CRA, as it is commonly utilized in the US. First, we worked with the questionnaire's total score and afterwards we proposed the validation of specific scores for risk behaviors associated to 'risky sexual behavior" and "risk due to drug use'.

\section{Assessment}

In the validation study we used a group of referees to observe and rate clinical vignettes obtained from selected patients in a cross sectional design. The referees were considered gold standards to validate the instrument and their assessments about the vignettes were the outcome. The study factor was the score obtained for each subject of each vignette.

\section{Preparation of clinical vignettes}

We selected thirteen volunteers who, according to the author's and the research group's best clinical decision, had problems compatible with three basic levels of exposure intensity to the HIV (low, medium, high). These subjects, after informed consent, were filmed using as a script the interview developed and administered by an interviewer of the research group. Vignettes of 15 'each were prepared. ${ }^{17}$ Before taping, the patient was asked to answer the CRA. The questions covered demographic features, type, beginning and development of the drug use pattern, and HIV condition reported by the respondent. Theses questions aimed mainly at clarifying the features and form of drug use, as well as the respondents' sexual preferences and habits to be further assessed by the referees. At the end, the interviewer asked the participant to give a personal score - from 1 to 10 - to the interview's reliability (the interviewer also did it separately). Recorded interviews were reviewed by the author, by the interviewer and by a psychiatrist alien to the research group and only the 10 vignettes that had a reliability score above 8 were chosen. The vignettes were then prepared in a written form by the interviewer as an auxiliary guideline to help referees in the validation.

\section{Building the validation instrument}

The validating instrument developed for referees to analyze the vignettes was composed by three questions. Questions were divided in two formats (Degree and Score), forcing the referee to choose from a three-point categorization (DEGREE: mild, moderate or severe) or from a five-point scale (SCORE: 1 to 5), being the last score the highest intensity.

\section{Selection of referees and assessment of vignettes}

Two groups of three referees considered as having expertise in their corresponding areas were invited to participate in the validation process. There was a session with three referees specialized in drug abuse, all of them psychiatrists with specific training in chemical dependence and with at least seven years of professional experience. The referees watched the videos and filled in the validation instruments of each case in separate. The procedure was repeated in a second stage with three referees specialized in HIV/AIDS. In this article, the first group of referees will be called Drug Referees and the second, HIV/ AIDS Referees.

\section{Data analysis}

\section{Construction of the frequency curve of the CRAs for the Overall Score}

While the instrument was validated, data collection was performed using the CRA in 695 subjects with similar features, in order to generate data about the rate of seropositivity and epidemiological elements for another study. From the first 235 cases initially assessed in a preliminary analysis, ${ }^{16}$ we built a frequency curve of total scores obtained from the simple addition of each answer of the instrument. We identified three main intervals (low, medium and high) of the total score to be used as initial parameters of the analysis. ${ }^{17}$ For control purposes, at the end of the study we built a second frequency curve based on the 695 collected cases, which was similar to the initial curve regarding the mean/mode/median or standard deviation from the mean. The Kolmogorov-Smirnov's test ("Goodness of Fit") confirmed that the distribution of score frequencies was normal. Analyses related to the overall score were, then, done based on 658 cases, as 37 collected cases did not have their questionnaires fully answered.

The data analysis used non-parametric ANOVA for the referees (Friedman's Test), and we chose to transform the categories into numbers. For the to analisys of the differences between categories, we used the chi-square test and the Wilcoxon's test for grouped pairs. The significance level was $5 \%$.

*Copies are available under request to the first author. 


\section{Results}

\section{Internal comparisons between referees}

The internal comparison between the first and the second group of referees can be seen in Table 1. According to the $p$ values, there were no significant differences between the impressions of Drug and HIV/AIDS Referees, respectively, suggesting that there was internal consistency among each group of referees.

Data analysis is initially based on the Overall Risk Score-ORS. Subsequent analyses on specific scores were performed: the Score for Drug Use - SDU - and the Score for Sexual Risk - SSR. SDU and SSR subscores were tested against the impressions of Drugs and HIV/AIDS Referees, respectively. When ORS, SDU and SSR were classified by mean and standard deviations from the mean, they generated cut-off scores described in Table 2. The Kolmogorov-Smirnov's (Goodness of Fit) test showed that their frequency distributions showed features comparable to the normal curve. Therefore, we chose to work with the distribution of scores around the mean and to identify intervals of one to two standard deviations from the mean, when possible.

\section{Overall Risk Score - ORS}

The CRA's questions used to compose the ORS dealt with drug use frequency in the 30 days and 6 months before the collection, partners and frequency of sexual relations, exchanges involving drugs/sex/money, relationships with potentially infected partners, use of condoms, and concern about the possibility of being contaminated or of transmitting/being reinfected by HIV, covering a time interval of six months before data collection. The answers to each question generated a total score (ORS) for each patient. Scores varied from 1 to 29 , with a mean of $11.56(+/-4.66)$ and mode and median of 11.

\section{Comparisons between referees and the ORS}

Table 3 shows the comparison between impressions of Drug Referees for the individual answers of the 10 vignettes. Degrees and scores were distributed around the mean of the ORS score. For the first question, two referees provided scores (indentified by the median) significantly different from the CRA, without significant differences in the remaining questions. Findings for degree were similar.

Table 1- Comparison between Drug and HIVIAIDS Referees (ANOVA for non-parametric data) about validating answers of the CRA.

\begin{tabular}{|c|c|c|c|c|c|c|c|c|}
\hline \multirow[t]{2}{*}{ Question of the validating instrument } & \multicolumn{4}{|c|}{ Median of Drug Referees } & \multicolumn{4}{|c|}{ Median of HIVIAIDS Referees } \\
\hline & Ref. 1 & Ref. 2 & Ref. 3 & $P^{*}$ & Ref. 1 & Ref. 2 & Ref. 3 & $\mathrm{P}^{*}$ \\
\hline 1. How involved/disturbed is the subject due to the use of drugs? & 3 & 3 & 2 & 0.24 & 3 & 3 & 3 & 0.59 \\
\hline 1a. Which score would you assign to the patient's involvement/disturbance? & 4 & 4 & 3 & 0.27 & 4 & 4 & 4 & 0.46 \\
\hline 2. What is the exposure degree of the subject to the HIV virus? & 2 & 1.5 & 2 & 0.51 & 3 & 3 & 2 & 0.29 \\
\hline 2a. Which score would you assign to his/her exposure? & 3 & 2.5 & 3 & 0.1 & 4 & 4 & 3 & 0.16 \\
\hline $\begin{array}{l}\text { 3. What is the risk of contamination (or re-contamination if the subject is } \\
\text { already positive) that you would assign to the subject's condition? }\end{array}$ & 2 & 1 & 2 & 0.59 & 2.5 & 2 & 1 & 0.39 \\
\hline 3a. Which score would you assign to the subject's risk of contamination? & 3 & 2 & 3 & 0.59 & 4 & 3.5 & 2 & 0.14 \\
\hline
\end{tabular}

*using the Chi-Square test.

Table 2 - Distribution of ORS, SDU and SSR scores (vignettes and sample) around the mean.

\begin{tabular}{|c|c|c|c|c|c|c|c|}
\hline \multirow{3}{*}{ SCORE } & \multirow{3}{*}{ Category } & \multicolumn{3}{|c|}{ Distribution of scores around the mean } & \multirow[b]{3}{*}{$\%$} & \multirow{2}{*}{\multicolumn{2}{|c|}{ All the sample }} \\
\hline & & Score interval* & Type & & & & \\
\hline & & & & $\mathrm{N}$ & & $\mathrm{N}$ & $\%$ \\
\hline \multirow[t]{4}{*}{ ORS } & Below $1 \mathrm{sd}$ from the mean & $1-6$ & Low & 2 & 20 & 92 & 14 \\
\hline & - 1 to 1 sd from the mean & $7-15$ & Middle & 7 & 70 & 468 & 71 \\
\hline & Above $1 \mathrm{sd}$ from the mean & 16 or more & High & 1 & 10 & 98 & 15 \\
\hline & & & Total & 10 & 100 & $658^{* *}$ & 100 \\
\hline \multirow[t]{4}{*}{ SDU } & Bellow 1 sd from the mean & Up to 5 & Low & 2 & 20 & 113 & 17 \\
\hline & - 1 to $1 \mathrm{sd}$ from the mean & 5 to 16 & Middle & 6 & 60 & 452 & 67 \\
\hline & Above $1 \mathrm{sd}$ from the mean & 17 or more & High & 2 & 20 & 104 & 16 \\
\hline & & & Total & 10 & 100 & $669^{* * *}$ & 100 \\
\hline \multirow[t]{4}{*}{ SSR } & Below $1 \mathrm{sd}$ from the mean & 0 to 6 & Low & 3 & 30 & 111 & 17 \\
\hline & - 1 to $1 \mathrm{sd}$ from the mean & 7 to 14 & High & 7 & 70 & 441 & 67 \\
\hline & Above $1 \mathrm{sd}$ from the mean & $---* * \star *$ & -- & 0 & 0 & 107 & 16 \\
\hline & & & Total & 10 & 100 & 659 & 100 \\
\hline
\end{tabular}

${ }^{*}$ When needed, scores were rounded

**In 37 cases we could not compute the ORS

***In 26 cases we could not obtain the SDU

****There were no cases above $1 \mathrm{sd}$ from the mean in this distribution.

Table 3 - Comparison of medians of answers assigned by Drug Referees to the questions related to risk degree and score with the ORS of studied

\begin{tabular}{|c|c|c|c|c|c|c|c|}
\hline \multirow[t]{2}{*}{$\begin{array}{l}\text { vignettes. } \\
\text { Question }\end{array}$} & \multirow{2}{*}{$\begin{array}{l}\text { Vignettes } \\
\text { med }\end{array}$} & \multicolumn{2}{|c|}{ Referee 1} & \multicolumn{2}{|c|}{ Referee 2} & \multicolumn{2}{|c|}{ Referee 3} \\
\hline & & med & $\mathrm{P}^{*}$ & med & $\mathrm{P}^{*}$ & med & $\mathrm{P}^{*}$ \\
\hline 1. How involved/disturbed is the subject due to the use of drugs? & 2 & 3 & 0.01 & 3 & 0.03 & 2 & 0.27 \\
\hline 1a. Which score would you assign to the patient's involvement/disturbance? & 2 & 2 & 0.69 & 1.5 & 0.36 & 2 & 0.74 \\
\hline 2. What is the exposure degree of the subject to the HIV virus? & 2 & 2 & 0.18 & 1 & 0.22 & 2 & 1.00 \\
\hline 2a. Which score would you assign to his/her exposure? & 3 & 4 & 0.01 & 4 & 0.02 & 3 & 0.35 \\
\hline $\begin{array}{l}\text { 3. What is the risk of contamination (or re-contamination if the subject is } \\
\text { already positive) that you would assign to the subject's condition? }\end{array}$ & 3 & 3 & 1.00 & 2.5 & 0.35 & 3 & 0.48 \\
\hline 3a. Which score would you assign to the subject's risk of contamination? & 3 & 3 & 0.27 & 2 & 0.12 & 3 & 1.00 \\
\hline
\end{tabular}

*Wilcoxon test for grouped pairs 
The same procedure was repeated to compare the impressions of HIV/AIDS Referees to the questions related to the ORS's risk degree and score, as is depicted in Table 4. The three referees had significantly different impressions about the findings of question 1 and the referee 2 had a different impression about the median of question 2. When HIV/AIDS Referees were compared with the risk scores we perceived a great number of impressions significantly different from those found by the instrument, except for question $2 \mathrm{a}$ for referee 3 and question $3 \mathrm{a}$ for referees 2 and 3 .

\section{Scores for Drug Use - SDU}

Questions utilized to build the SDU were about the use of intravenous drugs, drug use in the previous month, how often subjects went to shooting galleries, exchanges involving drugs/sex/money and concern with infection/transmission of the HIV. SDU's scores distribution had a mean of $11.34(\mathrm{sd}=4.89)$, mode $=8$, median $=11$, and ranged from 0 to 26 points. Comparisons between referees specialized in drugs and the SDU are in Table 5, with significant differences in the assignments of referees 1 and 2 for question 1. When Drug Referees had their score impressions compared to the findings of the SDU, we found significant differences in the first question for referees 1 and 2, and a significant difference in question 3 a for referee 2.

\section{Scores for Sexual Risk - SSR}

Questions used to build the SSR were about sexual relationships, exchanges involving drugs/sex/money, use of condoms and concern with infection/transmission of the HIV. Scores ranged from 1 to 26 , with a mean of 10.5 ( $\mathrm{SD}=4,2)$, mode of 10 and median of 10 . Table 6 illustrates the distribution of comparisons of HIV/AIDS Referees with the SSR in Scores. The comparisons between referees and the vignettes using the SSR for Degree showed that the three referees had different opinions as for question 1a, and referees 1 and 2 differed as for questions $2 \mathrm{a}$ and $3 \mathrm{a}$, and there was a borderline $\mathrm{p}$ value in the estimations of referee 2 as for question $3 a$.

\section{Discussion}

The validity of self reports in drug users has been discussed in the literature about HIV/AIDS. ${ }^{18-20}$ There are doubts whether the verification of complex behaviors such as risk exposure could be defined only by a number or a score, or even if it is clinically valid. Krupitsky* in Saint Petersburg used a sequence of independent translations of the RAB before achieving a final version. He did not verify its version concerning the referee's interrater reliability, assuming that their interviewers, as experienced psychiatrists, would collect the information in a very similar way, thus reinforcing the existent impression that data collection standardization would not be needed. Even considering that find-

Table 4 - Comparison of medians of answers assigned by HIVIAIDS Referees to the questions related to risk degree and score with the ORS of studied vignettes.

\begin{tabular}{|c|c|c|c|c|c|c|c|}
\hline \multirow[t]{2}{*}{ Question } & \multirow{2}{*}{$\begin{array}{l}\text { Vignettes } \\
\text { med }\end{array}$} & \multicolumn{2}{|c|}{ Referee 1} & \multicolumn{2}{|c|}{ Referee 2} & \multicolumn{2}{|c|}{ Referee 3} \\
\hline & & med & $p^{*}$ & med & $\mathrm{P}$ & med & $\mathrm{p}$ \\
\hline 1. How involved/disturbed is the subject due to the use of drugs? & 2 & 3 & 0.02 & 3 & 0.02 & 3 & 0.01 \\
\hline 1a. Which score would you assign to the patient's involvement/disturbance? & 2 & 2 & 0.14 & 3 & 0.03 & 2 & 0.74 \\
\hline 2. What is the exposure degree of the subject to the HIV virus? & 2 & 2.5 & 0.40 & 2 & 0.46 & 1 & 0.74 \\
\hline 2a. Which score would you assign to his/her exposure? & 3 & 4 & 0.01 & 4 & 0.01 & 4 & 0.01 \\
\hline $\begin{array}{l}\text { 3. What is the risk of contamination (or re-contamination if the subject is already } \\
\text { positive) that you would assign to the subject's condition? }\end{array}$ & 3 & 4 & 0.06 & 4 & 0.01 & 3 & 0.44 \\
\hline 3a. Which score would you assign to the subject's risk of contamination? & 3 & 4 & 0.05 & 3.5 & 0.13 & 2 & 0.68 \\
\hline
\end{tabular}

*Wilcoxon test for grouped pairs

Table 5 - Comparison of medians of answers assigned by Drug Referees to the questions related to risk degree and score with the SDU of studied

\begin{tabular}{|c|c|c|c|c|c|c|c|}
\hline \multirow[t]{2}{*}{$\begin{array}{l}\text { Vignettes. } \\
\text { Question }\end{array}$} & \multirow{2}{*}{$\begin{array}{l}\text { Vignettes } \\
\text { med }\end{array}$} & \multicolumn{2}{|c|}{ Referee 1} & \multicolumn{2}{|c|}{ Referee 2} & \multicolumn{2}{|c|}{ Referee 3} \\
\hline & & med & $\mathrm{p}$ & Med & $\mathrm{p}$ & med & $\mathrm{p}$ \\
\hline 1. How involved/disturbed is the subject due to the use of drugs? & 2 & 3 & 0.02 & 3 & 0.04 & 2 & 0.42 \\
\hline 1a. Which score would you assign to the patient's involvement/disturbance? & 2 & 2 & 1.00 & 1.5 & 0.22 & 2 & 1.00 \\
\hline 2. What is the exposure degree of the subject to the HIV virus? & 2 & 2 & 0.11 & 1 & 0.14 & 2 & 0.74 \\
\hline 2a. Which score would you assign to his/her exposure? & 3 & 4 & 0.02 & 4 & 0.03 & 3 & 0.50 \\
\hline $\begin{array}{l}\text { 3. What is the risk of contamination (or re-contamination if the subject is already } \\
\text { positive) that you would assign to the subject's condition? }\end{array}$ & 3 & 3 & 0.75 & 2.5 & 0.24 & 3 & 0.61 \\
\hline 3a. Which score would you assign to the subject's risk of contamination? & 3 & 3 & 0.18 & 2 & 0.09 & 3 & 0.86 \\
\hline
\end{tabular}

Table 6 - Values of the Wilcoxon's test using the distribution of the SSR around the mean - for DEGREE and SCORE - HIVIAIDS Referees

\begin{tabular}{|c|c|c|c|c|c|c|c|}
\hline \multirow[t]{2}{*}{ Question } & \multirow{2}{*}{$\begin{array}{l}\text { Vignettes } \\
\text { med }\end{array}$} & \multicolumn{2}{|c|}{ Referee 1} & \multicolumn{2}{|c|}{ Referee 2} & \multicolumn{2}{|c|}{ Referee 3} \\
\hline & & med & $\mathrm{P}$ & med & $\mathrm{P}$ & med & $\mathrm{P}$ \\
\hline 1. How involved/disturbed is the subject due to the use of drugs? & 2 & 3 & 0.01 & 3 & 0.01 & 3 & 0.01 \\
\hline 1a. Which score would you assign to the patient's involvement/disturbance? & 2 & 3 & 0.08 & 3 & 0.01 & 2 & 0.31 \\
\hline 2. What is the exposure degree of the subject to the HIV virus? & 2 & 2.5 & 0.16 & 2 & 0.21 & 1 & 0.74 \\
\hline 2a. Which score would you assign to his/her exposure? & 3 & 4 & 0.01 & 4 & 0.01 & 4 & 0.01 \\
\hline $\begin{array}{l}\text { 3. What is the risk of contamination (or re-contamination if the subject is already } \\
\text { positive) that you would assign to the subject's condition? }\end{array}$ & 3 & 4 & 0.04 & 4 & 0.01 & 3 & 0.21 \\
\hline 3a. Which score would you assign to the subject's risk of contamination? & 3 & 4 & 0.04 & 3.5 & 0.07 & 2 & 0.91 \\
\hline
\end{tabular}

*Krupistky E. Personal communication; 2001. 
ings about the concurrent validation of the instrument were not totally satisfactory, the authors stress the need to find standardized ways to verify exposure behaviors to HIV infection.

CRA findings were systematically different from the referees' impressions with regard to the estimation of the risk of being involved with HIV, and were constant for both subgroups of specialized judges which, as a whole, differed from that of the CRA. There were very little significant differences for questions 2 and 3 , suggesting that the estimations produced by the CRA for these questions have clinical validity, considering the possibility of using an integral risk score. SDU and SSR subscores had significant differences from the assignments given by referees, and the latter had clinical impressions that were again, as a whole, different from the CRA's estimations. The instrument's performance in questions 2 and 3 was insufficient, showing again that there are differences between referees and the CRA. We may consider, therefore, that the SSR and the SDU have lower clinical validity than the ORS, that also cannot express in a clinically valid way the involvement of the subject with the HIV virus, according to the validating process that was used. The better performance of the scores in the questions of Degree estimation reinforces the impression that for clinical professionals, for whom this instrument is supposed to have some utility in decision-making, it is easier to make a categoric than a numeric estimation.

Some assumptions must be considered here, in order to have a better understanding of the limits of this article:

The CRA questionnaire was adapted from an American instrument, based on the features of drug use in the urban population of Philadelphia and we had to face up with the total lack of instruments developed for this purpose in our local society. The translation of cultural elements poses some difficulties for the adaptation of the instrument into Portuguese, as in the Brazilian adaptation we suppressed some questions related to the use of drugs that do no exist in our society (e.g., heroine). Nevertheless, the instrument's form of assessment was maintained, to allow for future comparative analyses.

The lack of knowledge about the actual conditions of the local drug user led us not to take into account specific cultural aspects of our environment, what contributed for a partial view of the degree of substance use in the sample's subjects. The proposed correction for this bias would be a sequence of small qualitative studies (focal groups) with a modified version of the instrument or even its testing with bilingual subjects who preferentially had lived in both cultures; such method is quite more efficient to obtain qualitative information, but it requires a technology that the research group had not had for this kind of population.

Scores were calculated adding the raw score of each question, keeping the same weight for all of them. It is likely that if we develop a new instrument, the question about injecting cocaine would have a much greater weight than that about inhaling it, as there is a strong association between the use of intravenous drugs and seropositivity, as is shown by several recent studies. ${ }^{21-23}$

Differently from the versions of the American instrument,* the Brazilian RAB did not have its test-retest reliability assessed. This is another limitation of our study, as the stability of the obtained information was not tested in our society, preventing the generalization of findings.

In order to compare the referees' impressions we selected typical cases that would depict a range of risk severity in the patients' sample. ${ }^{17}$ It is very likely that the vignettes were not able to illustrate the range of variation of the risk behaviors to be measured by the CRA, especially as only 10 cases had been selected, and only those with proven reliability. The more severe cases - that would possibly provide the less reliable information - had been left apart. This is partly confirmed by the distribution of scores, which is around the normal one, despite having a greater concentration of cases on the left of the mean in the three distributions. This feature could be caused either by the actual distribution of cases in the population, or it could be an artifact caused by selection bias, by including only the least severe cases, as the subjects were interviewed by a "snow-ball" system and by conveniencesampling. It is possible that patients with a more pronounced risk awareness had come to these centers and that the instrument was not able to express the risk intensity by means of a high score. In summary, it is possible that due to the method utilized, the CRA may have detected risk intensities lower than those actually existent in the target population.

Moreover, it might be appropriate to review the validation questionnaire, using answers similar to the CRA, as they had even numbers and, therefore, force the respondent to have a more defined attitude, minimizing a potential trend of referees to choose answers that fall 'into the average.'

The way by which the SDU and SSR were built is different from that used in their place of origin. According to the authors of the original scale, ${ }^{14,15 * *}$ the RAB's final score is equal to the sum of drug and gender scores. In the format used in this article, there is a overlapping of questions between the specific scores, as we consider that they are part of risk behaviors that belong to both subscores. Therefore, the sum of individual scores surpasses the ORS's sum.

\section{Conclusions}

The CRA should be reformulated and added with questions to be used with risk-exposed drug users. It also needs the inclusion of a section about the use of intravenous drugs. The process of quantifying the risk may have been biased due to the vignettes chosen, and to the building method of the questionnaire of clinical validation, as the raw sum of scores of each question of the CRA might not express correctly the different risk intensities that the studied subjects are exposed to, which suggests the need to weigh the score of each answer by means of other analytical methods, such as principal component analysis. 
The CRA, in its overall risk expression by a score, is clinically valid to express the Exposure to and the Risk of infection/reinfection by HIV, but it is not clinically valid to measure any risk of being involved with the virus or harm caused by the exposure to the HIV. Its specific subscores (drugs and sex) were not clinically valid. It is possible that the way in which they were constructed,

\section{References}

1. Swan N. Contributions of behavioral research to AIDS studies recognized. NIDA Notes 1997;5/6:1-4.

2. Beach R, Mantero-Atienza E, Fordyce-Baum MK, Prineas RK, Zelaya E et al. HIV infection in Brazil. N Engl J Med 1989;321(12):830-2.

3. Cortes E, Detels R, Aboulafia D, Li XL, Moudgil T, Alam M, et al. HIV1, HIV-2, and HTLV-I infection in high-risk groups in Brazil. N Engl J Med 1989;320(15):953-8.

4. Guimarães MD, Castilho EA. Aspectos epidemiológicos da AIDS/HIV no Brasil. Rev Socied Bras Med Tropic 1993;26(2):101-11.

5. Figueiredo CRDL, Miranda VL, Marques LF. Diretrizes para projetos de redução de danos - documento preliminar. Ministério da Saúde, Programa Nacional de DST/AIDS; 1997.

6. Donohew L, Sypher HE, Bukoski WJ. Persuasive communication and drug abuse prevention, LEA. New Jersey; 1991.

7. Des Jarlais, Friedman SR, Friedmann P, Wenston JH, Sotheran JL et al. HIV/AIDS-related behavior change among injecting drug users in different national settings. AIDS 1995;9(6):611-7.

8. Des Jarlais DC, Hagan H, Friedman SR, Friedmann P, Goldberg D, Frischer $\mathrm{M}$, Green $\mathrm{S}$ et al. Maintaining low HIV seroprevalence in populations of infection drug users. J Am Med Assoc 1995;274(15):1226-31.

9. Dunn J, Laranjeira R. Desenvolvimento de entrevista estruturada para avaliar consumo de cocaína e comportamentos de risco. Rev Bras Psiquiatr 2000;22(1):11-6.

10. Dunn J, Laranjeira R. HIV-risk behavior among non-heroin using cocaine injectors and non-injectors in Sao Paulo, Brazil. AIDS Care 2000;12(4):471-81.

11. Telles PR, Bastos FI, Guydish J, Inciardi JÁ, Surratt HL et al. Risk behavior and HIV seroprevalence among injecting drug users in Rio de Janeiro, Brazil. AIDS 1997;1(supl 1):35S-42S.

12. Metzger D, Woody G, De Philippis D, McLellan AT, O’Brien CP, Platt JJ. Risk factors for needle sharing among methadone patients. Am J Psychiatr 1991;148(5):636-40.

13. Metzger D, Woody G, and McLellan AT. Twenty-four month seroconversion rates and behavioral change among injection drug users in-and-out-oftreatment. NIDA Epidemiologic Trends in Drug Abuse: Proceedings Community Epidemiology Work Group; Junho; 1992. p. 503-6.

14. Metzger DS. The risk assessment battery (RAB): Validity and reliability. Apresented in Sixth Annual Meeting of the National Cooperative Vaccine Development Groups for AIDS. Alexandria,VA; 1993. with several questions that occasionally were part of both scores, might contribute for a lower expression of its clinical validity.

\section{Acknowledgments}

The authors thanks Luis Augusto Paim Rohde, MD, for his valuable suggestions in the preparation of this manuscript.
15. Navaline H, Snider E, Christopher JP, Tobin D, Metzger D et al. Preparations for AIDS vaccine trials. An automated version of the Risk Assessment Batery: enhancing the assessment of risk behaviors. Aids Res Hum Retrov 1994;10(2):S281-3.

16. Pechansky F, Soibelman M, Kohlrausch E. Assessment of risk situations for HIV transmission among drug abusers in Porto Alegre, Brazil. J Drug Issues 1997;27(1):147-54.

17. Pechansky F, Letti K. Utilidade e validação do questionário de comportamento de risco para AIDS (CRA) em Porto Alegre - Relatório Preliminar. Anais da XVIII Jornada SulRioGrandense de Psiquiatria Dinâmica, CELG; 1996.

18. Greenfield L, Beigelow GE, Brooner RK. Validity of intravenous drug abusers' self-reported changes in high-risk drug use behaviors. Drug Alcohol Depend 1997;39:91-8.

19. Needle R. The reliability of self-reported HIV risk behaviors of drug users. Psychol Addic Behav 1995;9:242-50.

20. Odo SA, Araujo AC, Santos AF, Toledo FC, Yonamine M, Silva O et al. Consumo de maconha entre dependentes de cocaína em tratamento ambulatorial: níveis de consumo, confiabilidade do relato e implicações para o tratamento. Rev Psiquiatr Clínic 2000;27(1):43-9.

21. Pechansky F, Inciardi J, Surratt H, Lima AF, Kessler F, et al. Um estudo exploratório sobre as características de usuários de drogas injetáveis que buscam atendimento em Porto Alegre. Rev Bras Psiquiatr 2000;22(4):164-71.

22. Pechansky F. Modelo teórico de exposição a risco para transmissão do vírus HIV em usuários de drogas. Rev Bras Psiquiatr 2001;23(1):39-45.

23. Pechansky F, Von Diemen L, Genro V. Presença de situações de risco para a transmissão do HIV em usuários de drogas não injetáveis. Rev Psiquiatr Clínic 2001;28(3):157-9.

\section{Correspondence:}

Flavio Pechansky

Rua Itaqui, 89/103

90460-140 Porto Alegre, RS, Brazil

Tel./Fax: (0xx51) 3330-1845

E-mail: Fpechans@uol.com.br 